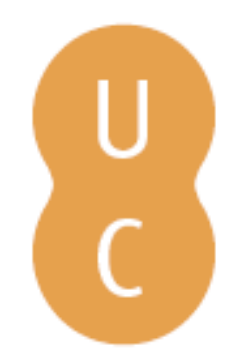

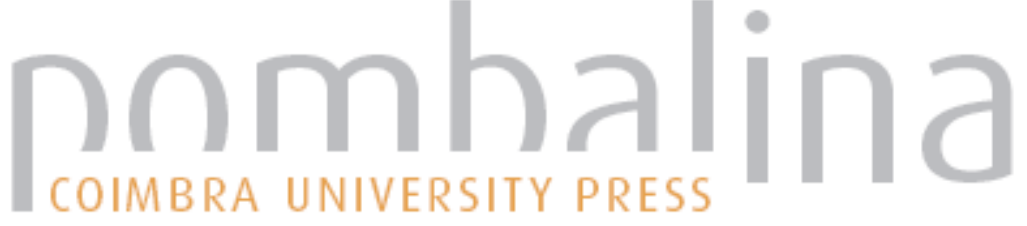

\section{Pasteur in Portugal: public health and the diffusion of hygiene}

Autor(es): $\quad$ Pereira, Ana Leonor; Pita, João Rui

Publicado por: Imprensa da Universidade de Coimbra

URL

persistente:

URI:http://hdl.handle.net/10316.2/32373

DOI:

DOI:http://dx.doi.org/10.14195/978-989-26-0233-2_2

Accessed : $\quad$ 26-Apr-2023 14:31:00

A navegação consulta e descarregamento dos títulos inseridos nas Bibliotecas Digitais UC Digitalis, UC Pombalina e UC Impactum, pressupõem a aceitação plena e sem reservas dos Termos e Condições de Uso destas Bibliotecas Digitais, disponíveis em https://digitalis.uc.pt/pt-pt/termos.

Conforme exposto nos referidos Termos e Condições de Uso, o descarregamento de títulos de acesso restrito requer uma licença válida de autorização devendo o utilizador aceder ao(s) documento(s) a partir de um endereço de IP da instituição detentora da supramencionada licença.

Ao utilizador é apenas permitido o descarregamento para uso pessoal, pelo que o emprego do(s) título(s) descarregado(s) para outro fim, designadamente comercial, carece de autorização do respetivo autor ou editor da obra.

Na medida em que todas as obras da UC Digitalis se encontram protegidas pelo Código do Direito de Autor e Direitos Conexos e demais legislação aplicável, toda a cópia, parcial ou total, deste documento, nos casos em que é legalmente admitida, deverá conter ou fazer-se acompanhar por este aviso. 
Philip Rieder Ana Lennar Pereira Jaão Rui Pita

\section{História \\ Ecológico-Institurional da Borpo}

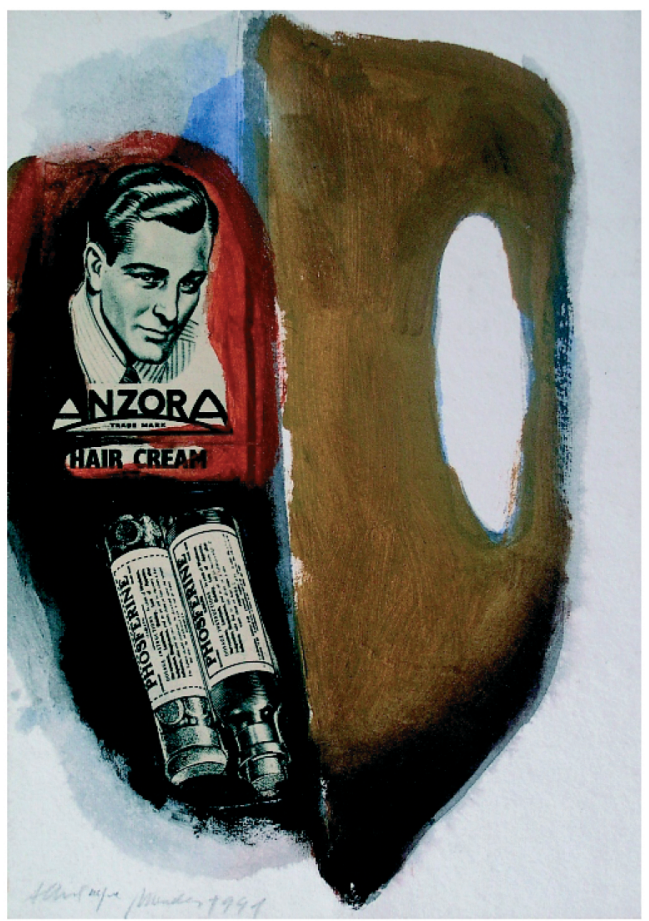


(Página deixada propositadamente em branco) 


\section{PHILIP RIEDER \\ ANA LEDNDR PEREIRA \\ JQÃ̃ RU PITA}

\section{HISTÍR|A \\ ECDLĹCI|CD-INSTITUCIONAL \\ प्रि टारिए}

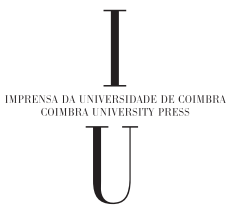

- colmbra 2006 
(Página deixada propositadamente em branco) 
(Página deixada propositadamente em branco) 


\section{Coordenação Científica da Colecção Ciências e Culturas}

João Rui Pita e Ana Leonor Pereira

Os originais enviados são sujeitos a apreciação científica por referees

Coordenação Editorial

Maria João Padez Ferreira de Castro

\section{Edição}

Imprensa da Universidade de Coimbra

Email: impresauc@ci.uc.pt

URL: http://www.imp.uc.pt • Normas de publicação de colecçôes

Design

António Barros

Pré-Impressão

António Resende

Imprensa da Universidade de Coimbra

\section{Capa}

Albuquerque Mendes

"Anzora», 1991

Acrílico e colagem sobre papel

Col. António Barros, Coimbra

Impressão e Acabamento

SerSilito - Maia

ISBN

978-989-8074-14-0

Depósito Legal

$263188 / 07$

Obra publicada com a colaboração de:

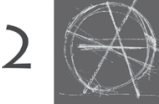

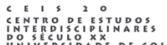

Obra publicada com o apoio de:

FCT Fundação para a Ciência e a Tecnologia

MINISTÉRIO DA CIÊNCIA, TECNOLOGIA E ENSINO SUPERIOR Portuga

Programa Operacional Ciência, Tecnologia, Inovação do Quadro Comunitário de Apoio III

(C) 2006, Imprensa da Universidade de Coimbra 


\author{
Ana Leonor Pereira* e João Rui Pita** \\ * Faculdade de Letras e CEIS 20, Universidade de Coimbra, Portugal \\ ** Faculdade de Farmácia e CEIS 20, Universidade de Coimbra, Portugal
}

\title{
Pasteur in Portugal: \\ PUBLIC HEALTH AND THE DIFFUSION OF HYGIENE ${ }^{1}$
}

\section{Introduction}

Portugal and France have many historical affinities, especially in the field of culture and in the scientific domain ${ }^{2}$. As far as biomedical science is concerned, there are many determinant examples of the French influence: suffice it to mention Pasteur ${ }^{3}$ and microbiology, and its relation to hygiene and public health ${ }^{4}$. The impact of Pasteurian mentality on Portuguese scientific biomedical and administrative communities, as well as its diffusion within the great public, has been the object of our research.

We carried out two case studies that constitute the basis of the current intervention.

1. The foundation of the three most important laboratories in the fields of hygiene and public health, at the end of the $19^{\text {th }}$ century: a) Microbiology Office of the University of Coimbra; b) Municipal Chemistry Lab of Oporto; c) Bacteriological Institute of Lisbon.

\footnotetext{
${ }^{1}$ Research project: História Ecológico-Institucional do Corpo (1900-1950). O caso português / Public and private ecological-institucional history of the body (1900-1950) - The Portuguese case (Fundação para a Ciência e a Tecnologia, F.C.T. - POCTI / HAR / 49941 / 2002). Translation: Patrícia Martins.

${ }^{2}$ See Ana Leonor Pereira; João Rui Pita, «Ce qu’on pensa au Portugal, au cours du temps, de la France scientifique», Revue d'Histoire de la Pharmacie, Paris, 45 (316) 1997, pp. 429-430.

${ }^{3}$ See Ana Leonor Pereira; João Rui Pita; Sérgio Namorado, «Pasteur em Portugal. A recepção da mentalidade etiopatológica em Portugal», Revista Portuguesa de Farmácia, 51(4)2001, pp. 183-191. João Rui Pita; Ana Leonor Pereira; Sérgio Namorado; Ricardo Gonçalves, «Pasteur na cultura científica portuguesa entre 1880 e 1920 - Mosaico de fonts». In: Actas da Reunião Internacional de História da Medicina, Lisboa, 11 a 13 de Outubro de 2001, Lisboa, Faculdade de Ciências Médicas-UNL/Sociedade de Geografia de Lisboa/Societas Internationalis Historiae Medicinae, 2003, pp. 244-246; Ana Leonor Pereira; João Rui Pita; Sérgio Namorado; Ricardo Gonçalves, "Condição humana e criatividade científica. Pasteur: a ciência ao serviço do Bem». In: Actas da Reunião Internacional de História da Medicina, Lisboa, 11 a 13 de Outubro de 2001, ob. cit., pp. 247-248.

${ }^{4}$ See Ana Leonor Pereira; João Rui Pita, "Ciência e medicina: a revolução pasteuriana», Congresso Comemorativo do V Centenário do Hospital do Espírito Santo de Évora - Actas, Évora, Hospital do Espírito Santo de Évora, 1996, pp. 245-271.
} 
2. The magazine A Illustração, a periodical of political, cultural and scientific news printed in Paris, which diffused themes concerning public health to the great public, inspired on Pasteur's work.

\section{The foundation of hygiene laboratories: chemical and microbiological labs}

At the end of the $19^{\text {th }}$ century three labs were founded in Portugal with very different institutional origins, different practical aims, but converging final aims: paying service to public health, since chemical and microbiological analyses of application to private and public health were made there.

In 1882 the foundation of the Microbiology Office of the University of Coimbra began, being institutionalised in 1886. In 1884 the Municipal Chemistry Lab of Oporto was founded, as a dependent institution of Oporto City Hall. In 1892 the Bacteriological Institute of Lisbon was founded following state initiative, which assumed itself as responsible entity for bacteriological analysis in Portugal.

Our aim is to evaluate Pasteurian influence on the foundation of the three labs, the scientific practice the three labs carried out to serve the population and the relation between these three labs and Portuguese sanitary administration.

\subsection{The Microbiology Office of the Faculty of Medicine, University of Coimbra}

The Microbiology office of Coimbra's Faculty of Medicine was first established in 1882 but was only institutionalised in $1886^{5}$. It was the first establishment of this kind to be founded in Portugal ${ }^{6}$. In the academic year 1882-83, Augusto Rocha, Professor of General Pathology, started teaching bacteriology in his chair, following other European models that added bacteriology to pathology, hygiene and medical practice chairs. Augusto Rocha was totally aware that bacteriological studies were indispensable in the instruction of doctors. His pioneering initiative in Portugal had to face difficulties in creating a specific lab to the teaching of bacteriology. Augusto Rocha, contrarily to other professors, believed that bacteriology teaching should have a strong practical component. At first, practice was carried out in the Histology Lab of the Faculty of Medicine. In 1883 and 1884 several sums were asked to the Faculty of Medicine Council and other institutions ${ }^{7}$ to start the acquisition of elementary lab material. However, the lab's institutionalisation was difficult because there was strong divergence concerning the conditions of its functioning and the curricular imposition

\footnotetext{
5 See Ana Leonor Pereira; João Rui Pita, "A 'nave' dos micróbios na Universidade de Coimbra». In: Património Cultural em Análise (Actas do Encontro Nacional), Coimbra, GAAC, 1998, pp. 113-127.

${ }^{6}$ Charles Lepierre, Laboratoire de microbiologie et de chimie biologique. Notice historique, Coimbra, Imprimerie de l'Université, 1906, p. 4.

${ }^{7}$ See Charles Lepierre, Laboratoire de microbiologie et de chimie biologique. Notice historique, ob.cit., p. 5-6; Augusto Rocha, "Documentos para a historia de um futuro Gabinete de bacterioscopia na Faculdade de Medicina», Coimbra Médica, 6 (11) Jun. 1886, p. 169.
} 
of bacteriology teaching in the medical degree ${ }^{8}$. In 1886, the Microbiology Office was institutionalised with weak economic resources ${ }^{9}$, Augusto Rocha being its first director. He kept this office until 1892 when he was replaced by professor Luís Pereira da $\operatorname{Costa}^{10}$. In 1911 microbiology became an autonomous subject of the medical degree with the introduction of Bacteriology and Parasitology chairs.

Augusto Rocha made several scientific expeditions to Paris, Amsterdam, Berlin, Brussels and Vienna. He visited microbiological labs, namely Pasteur's and Koch's ${ }^{11}$, with the purpose of adequately equipping the University of Coimbra's lab and keeping it up-to-date.

From 1882 to 1902 , the lab was called Microbiology Office. In 1890, this lab started having its own facilities. In 1902 its name changed to Microbiology and Biological Chemistry Lab because a new area, that of biological chemistry, had emerged. This was especially due to the effort of the French scientist Charles Lepierre, who made his career in Portugal after 1888. Up to 1911, Charles Lepierre worked in Coimbra, then he moved to Lisbon, where he died in 1945. His influence was decisive in the diffusion of Pasteurian science in Portugal ${ }^{12}$.

At first, the Microbiology office had the following functions: practical teaching of bacteriology and parasitology; microbiological and serologic analysis; preparation of vaccines to Coimbra's University Hospitals; hydrologic analysis to Coimbra's waters; analysis to meat of public consumption that came from the municipal slaughter-house; carrying out research work. Besides all this, Augusto Rocha had the diffusion of rabies vaccine in mind, according to the Pasteurian method ${ }^{13}$.

The first work carried out in the Microbiology Office, a scientific article, was Filomeno da Câmara and Augusto Rocha’s responsibility. It was entitled Investigação do «Bacillus Typhicus» nas Aguas potaveis de Coimbra and was published in several parts in the magazine Coimbra Médica ${ }^{14}$. It was carried out at Coimbra Civil Government request.

\footnotetext{
${ }^{8}$ Actas das Sessōes da Faculdade de Medicina. See: Acta de 7 de Julho de 1885. A.U.C. - 1ªD-3-1-91-Livro, fl. 124 vº-125; Acta de 12 de Dezembro de 1883. In: Actas da Faculdade de Medicina, 1878-1886, p. 84. A.U.C. - $1^{\text {a }}$ D-3-1-91 - Livro. See Augusto Rocha, "Documentos para a historia de um futuro Gabinete de bacterioscopia na Faculdade de Medicina», art. cit., pp. 168-169.

${ }^{9}$ Ibid, p. 186.

${ }^{10}$ Augusto Rocha left the direction of the lab because he became professor of a different subject.

${ }^{11}$ See Acta da Sessão Extraordinária de 22 de Fevereiro de 1890. A.U.C. - 1a D-3-1-92 - Livro, fls. $61 v^{\circ}-62$.

12 See Ana Leonor Pereira; João Rui Pita, "Charles Lepierre au Portugal (1867-1945). Son influence décisive sur la santé publique, sur la chimie et sur la microbiologie», Revue d'Histoire de la Pharmacie, Paris, 328, 2000, pp. 463-470.

${ }^{13}$ See Augusto Rocha, «A raiva», Coimbra Médica, 7(2) 1887, pp. 28-29.

${ }^{14}$ See Filomeno da Câmara Melo Cabral; Augusto Rocha , "Investigação do 'Baccillus Typhicus' nas aguas potaveis de Coimbra", Coimbra Médica, 7(18)1887, pp. 277-283; 7(19)1887, pp. 293-296; 7(20)1887, pp. 309-316; 7(21)1887, pp. 325-331; 7(22)1887, pp. 341-347; 7(23)1887, pp. 363-365; 7(24)1887, pp. 377-379; 8(1)1888, pp. 6-9; 8 (2) 1888, pp. 35-38; 8(3)1888, pp. 49-51; 8(5)1888, pp. 82-86; 8(6)1888, pp. 93-98; 8(10)1888, pp. 157-163; 8(17)1888, pp. 269-171; 8(21)1888, pp. 336; 9(1)1889, pp. $12-14$.
} 
Besides Augusto Rocha and Filomeno da Câmara, other authors carried out work in the Microbiology Office during the first twenty-five years, such as: Luís Pereira da Costa, Virgílio Poiares, Vieira de Campos, António Cagigal, Angelo da Fonseca, António de Pádua, Nogueira Lobo, Marques dos Santos, Álvaro Matos, Geraldino Brites and Sérgio Calisto. Among these, there is an author that stands out - the French chemical engineer mentioned above, Charles Lepierre. His name stands out due to the amount and importance of work carried out especially in the field of microbiological analysis applied to public health. Much of the work made in this lab had fundamental interest to public health. Research work in this lab fed the constant tutelary presence of Pasteur's scientific spirit - the "most glorious figure of France» 15 and "wonderful genius» ${ }^{16}$ in Augusto Rocha's words.

\subsection{Municipal Chemistry Lab of Oporto}

The Municipal Chemistry Lab of Oporto was created in 1884 , although the process of its establishment had started in 1882, with the engagement of Correia de Barros, the city's Mayor. The main objective of that Lab was the analysis to suspect food items. According to its rules, analyses to other products were also possible but only with permission of the one responsible for the lab. Analysis could be carried out either at private or official level, following the population's request. In that case, the fees charged would be low.

The prestigious chemist A. J. Ferreira da Silva was chosen to direct the Lab. In 1883 he went to Paris to learn how to equip it. Ferreira da Silva was Professor in the Polytechnic School until 1911 and then in the Faculty of Science of the University of Oporto, and he left a vast work in the field of chemistry applied to public health or "hygienic chemistry», according to the expression used at the time.

The good organisation of the lab and the quality of the analyses made there were reflected in the image of the city of Oporto, which became more and more identified with the following motto: »economic and material progress of peoples is entirely related to the fervent worship of experimental science» ${ }^{17}$.

In 1907 Oporto City Hall decided to extinguish the Chemistry Lab. This measure provoked polemics and the disagreement of many Portuguese scientific and professional institutions. The decision was justified by the economic untenability of the Chemistry Lab.

For approximately twenty years, the Municipal Chemistry Lab of Oporto exerted its activity defending the interests of private and public health, carrying out 10.487 analyses, divided as follows: analyses of food items (7.726); analyses of application to medicine (1.501); analyses of industrial and commercial products (531); toxicological analyses (282); analyses of medicines (240); diverse analyses (174); analyses of manure

\footnotetext{
15 See Augusto Rocha, "A raiva», Coimbra Médica, 7 (2) 1887, p. 28.

${ }^{16}$ See Augusto Rocha, "A raiva», Coimbra Médica, 7 (2) 1887, p. 29

${ }^{17}$ See Revista de Chimica Pura e Applicada, 3 (8) 1907, p. 370.
} 
and soils $(33)^{18}$. Analyses of food items accounted for more than $70 \%$ of the analyses carried out, according to the primary aims of the lab.

In the Municipal Chemistry Lab of Oporto, pioneering analyses were carried out in the field of public health in Portugal, and it is important to emphasize that many of these analyses had direct consequences on Portuguese economy. For example: analyses of wine, namely Porto wine, which represented an important economic value and constituted an immeasurable socio-cultural good of Portugal's identification. There are other examples - fire-water, olive oil, milk, salt, etc. -, also valuable within the general frame of Portuguese economy and public health.

\subsection{Bacteriological Institute of Lisbon}

The Bacteriological Institute of Lisbon was founded by Decree on the $29^{\text {th }}$ December 1892. Its creation was based on the need of an official scientific establishment of microbiological analyses in Portugal, which would follow Pasteurian scientific rules. Progress made in France in the field of microbiology through Pasteur, like vaccination against rabies, gave other countries optimistic reasons to invest in bacteriological labs. This accounts for what happened in Portugal as well. Since the diffusion of rabies vaccine, several Portuguese doctors and scientists became interested in this breakthrough. Some of them went to Paris to deepen their knowledge on this question. Not everyone agreed about the high value of Pasteur's breakthroughs. For example, Eduardo Burnay and Eduardo Abreu, two prestigious Portuguese physicians defended different positions, the latest being very sceptical as far as the rabies vaccine was concerned. Therefore, the rulers decided to solicit the Medical Science Society a report on this subject. For roughly five months this subject was discussed in the medical Society. Among several positions in favour of Pasteurian vaccination, the opinions of two famous doctors stand out: Sousa Martins and Miguel Bombarda's. In a session on the $6^{\text {th }}$ August 1887, the Medical Science Society of Lisbon, through Miguel Bombarda's report, defended the creation of a Bacteriological Institute in Lisbon, dedicated to anti-rabies vaccination and to other functions. The Portuguese medical scientist Luís Câmara Pestana had a decisive role in the creation of the Bacteriological Institute of Lisbon ${ }^{19}$. In 1891, with a scholarship conceded by the Government, Câmara Pestana did training in Germany and in Paris. In the French capital, he had contacts with Émil Roux, which were essential to his scientific instruction. The Bacteriological Institute of Lisbon had its facilities in a small space of S. José Hospital and in 1896 the construction of a new building started. The Government had assumed the objective of equipping the country with a Pasteurian lab like other countries were doing. Queen Amélia assumed the responsibility for the Institute's construction, and the medical scientist

\footnotetext{
${ }^{18}$ See «A extincção do Laboratorio Municipal», Revista de Chimica Pura e Applicada, 3(6)1907, p. 211.

${ }^{19}$ See João Rui Pita; Ana Leonor Pereira; Ricardo Gonçalves, «Câmara Pestana: figura internacional da microbiologia». In: Actas da Reuniāo Internacional de História da Medicina, Lisboa, 11 a 13 de Outubro de 2001, ob. cit., pp. 242-243; Ana Leonor Pereira; Joāo Rui Pita; Ricardo Gonçalves, "Curar e prevenir: ciência, técnica e arte. O exemplo de Câmara Pestana». In: Actas da Reunião Internacional de História da Medicina, Lisboa, 11 a 13 de Outubro de 2001, ob. cit., pp. 249-250.
} 
Câmara Pestana became her most active adviser. The new building was located in Lisbon city centre, close to S. José Hospital and the Medico-surgical School. It was projected by architect Romano Folque, after having consulted the French scientist Émile Roux, and it was built under Xavier da Silva's direction; it was composed of seven buildings, including the Lab, Rabies Hospital and Diphtheria Hospital. The Bacteriological Institute had the mission of carrying out the analyses solicited by the Government, the Medico-surgical School of Lisbon and S. José Royal Hospital. The new building was inaugurated in 1900. Câmara Pestana had died the previous year, a victim of plague epidemics that occurred in the city of Oporto and was exemplarily studied and fought ${ }^{20}$. Câmara Pestana was one of the many martyrs of science since he lost his life researching on the causes of epidemics in the city of Oporto in the proper places. The Bacteriological Institute was named after Câmara Pestana in homage to its first director, who was also a martyr of science.

Bacteriological studies on the waters that supplied the city of Lisbon were a priority. In fact, innumerable studies were carried out on this issue.

The Bacteriological Institute Câmara Pestana has had an important role as a lab of public health and bacteriology centre for the last 100 years. Up to the present day, the Institute has developed fundamental actions in the field of public health, particularly in the areas of diphtheria, rabies, carbuncles, clinical microbiology and verification of biological products. It educated several generations of microbiologists attentive to scientific innovation and linked to other centres abroad, through trainings, etc. It is possible to say that the Bacteriological Institute Câmara Pestana has been a school of scientific research at international level since its beginning.

\section{The magazine $A$ Illustração}

From 1884 to 1892 the magazine A Illustração was published. It was a Portuguese fortnightly magazine of political, cultural and scientific news, printed in Paris, in the Portuguese language, edited by a Portuguese man — Mariano Pina. Up to 1890 it had its editorial office in Paris and then in Lisbon ${ }^{21}$. This was the illustrated magazine in the Portuguese language of biggest circulation in Portugal and Brazil (15.000 copies), and it followed the model of some European newspapers like Le Monde Illustré, Illlustration, Graphic, Illustrated London News and Illustrirte Zeitung. Portuguese artists of the last quarter of the $19^{\text {th }}$ century were collaborators in this magazine $e^{22}$ and texts of Portuguese prestigious authors were published in the literary anthology ${ }^{23}$.

\footnotetext{
20 See Ana Leonor Pereira, "Novas sensibilidades científico-culturais em Portugal na aurora do séc. XX». In: Estudos de história contemporânea portuguesa. Homenagem ao Professor Vitor de Sá, Lisboa, Livros Horizonte, 1991, pp. 421-431.

${ }^{21}$ See Ana Leonor Pereira; João Rui Pita, «La publicité pharmaceutique, médicale et cosmétique dans la revue A Illustração", Revue d'Histoire de la Pharmacie, Paris, 309, 1996, pp. 159-168.

${ }^{22}$ For example: Antero de Quental, Columbano, Conde Ficalho, Eça de Queirós, Fialho de Almeida, Ramalho Ortigão, Guerra Junqueiro, Cesário Verde, António Feijó, Oliveira Martins, Rafael Bordallo Pinheiro e Teófilo Braga.

${ }^{23}$ For example: Camões, João de Deus, Bocage, Nicolau Tolentino, Gonçalves Crespo, etc.
} 
The number of pages dedicated to the diffusion of cultural, political, scientific and technical work in France emphasizes the quality of this magazine and, at the same time, it testifies the paradigmatic value of France to Portugal. As far as scientific questions are concerned, we realise that the magazine gave French scientific diffusion a special place. In fact, French scientific production justified its regular diffusion among the scientific community and the public in general. The magazine $A$ Illustração also presented the gallery of French and European scientists to the Portuguese public, with a special emphasis on Pasteur's life and work. Pasteur was "the big hero of the time» and France was "among all the nations in the world, the most beautiful and respectable for its great work of spirit". Several articles presented the progress of Pasteurian research and the benefits that Pasteur's breakthroughs brought to Humanity. There are also reports on visits of foreign researchers to Paris in order to verify the value of Pasteurian results. A Illustração never doubted of Pasteur's work. It always tried to show the benefits of his work, diffusing well succeeded news and testimonies. For example, it reported the case of a group of Portuguese sick people attacked by rabies, who went to Pasteur's Lab and were very happy with the assistance paid there.

To emphasize the impact of French science in Portugal even further, it must be pointed out that many questions of public health were approached having French reality as a point of departure. Every time the magazine approached the theme of cholera epidemics, it took French experience as a point of departure, for example, cholera in Paris, in Toulon, in Marseille and in the Franco-Italian border.

Private hygiene associated to cosmetics received a treatment similar to that of public hygiene. Therefore, the reader had regular access to a vast thematic diversity that included particularly: tuberculosis, water microbes, typhoid fever microbe, the sanitary state of the main cities in Europe, hygiene in dwellings, graves and cremations, congresses on hygiene and demography, alcoholism, yellow fever, leprosy epidemics, scarlet fever, children's hygiene, food falsifications, labour hygiene, excess of population, hair hygiene, sea baths, ladies' hairdressing, baldness, depilatories, female beauty, etc..

Also in the field of advertising, A Illustração elected France as a model to be followed. Almost all ads concerned products of French origin and their publishing followed what was being practised by French magazines and newspapers, which were in harmony with the great medical, hygienic and cosmetic concerns of the last quarter of the $19^{\text {th }}$ century. In every number, A Illustração kept considerable place for advertising. From a whole of 3.588 advertisements, 1.802 were related to cosmetics and products of body hygiene, 1.233 were related to medicines, minero-medicinal waters and food items, and the other 553 advertisements were related to several articles.

The magazine $A$ Illustração had a relevant function in diffusing and educating about scientific hygiene, i.e., lab hygiene articulated with the progress verified mainly in the fields of analytic chemistry and microbiology. Considering the great spread of contagious diseases like cholera and tuberculosis at the end of the $19^{\text {th }}$ century, widely announced in the magazine, it is not surprising that the medicines the most advertised for were meant to struggle against physical debility and respiratory affections.

Advertisements to cosmetics and products of body hygiene were in harmony with the dominant concept of beauty and contributed to define that same concept, namely in defending fair skin as the attainable ideal of female beauty. Private hygiene was 
not only synonymous to washed and healthy body. Associated to cosmetics, private hygiene soon acquired social and communicational importance, i.e., it imposed itself as a language that has become more and more complex according to age and gender.

\section{Conclusion}

Both within an institutional frame and a frame of scientific practice, Portugal followed the French scientific model, and this can be illustrated by the reception of Pasteurian science in Portugal. This reception of Pasteur was not exclusive to the Portuguese case. It happened everywhere and all over the world, which is normal if we bear in mind the unique place occupied by Pasteur in the universal history of science.

However, by following the French style of scientific diffusion and public education within the journalistic frame, Portugal shows deep cultural affinity with France.

This interesting scientific-cultural way of being is understandable in the light of the compared history of both countries. 
(Página deixada propositadamente em branco) 


\section{Colecçẫo \\ Ciências e Culturas \\ Coimbra 2006}

